\title{
Coaches: Pedagogues of Sport? Methodological Attempt to Study the Pedagogical Beliefs of Hungarian Football Coaches
}
Authors' contribution:
A) conception and design of the study
B) acquisition of data
C) analysis and interpretation of data
D) manuscript preparation
E) obtaining funding

Dániel Varga

University of Physical Education, Hungary
KEYWORDS

\begin{abstract}
Not only are coaches supposed to be excellent in their sports, but they should also be good pedagogues. However, according to public opinion, most coaches' only aim is to reach the highest performance possible with their athletes. The objective of this paper is to examine whether this common assumption is also true of football coaches. Adapting the concept of a nationwide study of teachers' pedagogical views, the author attempts to discover Hungarian football coaches' pedagogical beliefs, their opinions on the most important tools of education, the content of human values transmitted during education, and their educational creeds. At the same time, the paper analyzes how the conceptual framework and the methods used in the research among the teachers can be transformed to the special conditions regarding the coaches' work. The results of the research show how the football coaches interpret the term "education," what they think about the most influential tools of education, and which educational values and creeds they identify themselves. The conclusion of the paper is that both the findings of a pilot study among football coaches and the adaptation of the methods used in the research to reveal the teachers' pedagogical views proved to be beneficial and instructive.
\end{abstract}

pedagogical views, educational values, educational creeds, methodological consideration, football coach

\section{Introduction}

A scientifically proven statement is that all forms of sport are important tools in the development of a personality. From this statement, we may conclude that coaches make plans for and pay attention to the development processes of their athletes. However, it is not generally accepted in the realm of public opinion that the main aim of coaches is not just to increase performance, but also to consciously organize valuable educational work, which is an integral part of their core activities. In the case of teachers, it is evident that the social perception of their activities depends on their educational goals. Conversely, the fact that permanent improvement in athletes' achievements is considered the primary purpose of sporting activities makes it more difficult to see coaches' attitudes towards educational goals. 
However, if we assume that sports activities are an effective and efficient means of developing personality, then we can state that regarding coaches as pedagogues is a possible interpretation. As S. Szabó explained, beside other characteristics, "The coach is a teacher, the coach is an educator, he/she has to be a good specialist in pedagogy. He/she has to show a good pattern for the competitors, having discussions sometimes not only about sport, but real life, problems, school, family, social situations, etc. In other words, a coach has to be a good pedagogue, having also the capability to handle conflicts" (Szabó 2012, p. 41).

This line of thinking appears in the concept of international coaching organizations. In a document about the recognition and support of coaches formulated by the International Council for Coaching Excellence (ICCE) and the Association for Summer Olympic International Federations (ASOIF), it is highlighted that:

Coaches play a central role in promoting sports participation and enhancing the performance of athletes and teams. In accordance with internationally recognized and domestic sporting codes, coaches guide the participation of children, players and athletes... In addition to their core role, coaches contribute to the development of athletes as people, teams as cohesive units and communities with a shared interest... Coaches are required to fulfil a variety of roles that may include educator, guide, sport psychologist and business manager. (International Sport Coaching Framework 2012, p. 4)

Despite the similarity between the scientific and protection-oriented approach to coaching, in reality it is a more complex issue. It seems that, in practice, coaches themselves often limit their roles to performance enhancement. Their activities frequently become one-sided, and they lose different areas and opportunities for education. Therefore, the professional training of coaches and the examination of the pedagogical beliefs guiding their activities during their daily work are of outstanding importance.

\section{Literature review}

The fact that coaches play a central role in sport is reflected by a rich scientific literature. Their profession and their personalities have been studied from different perspectives in social sciences (e.g., psychological, sociological, pedagogical, and philosophical perspectives) with the help of various quantitative and qualitative methods. Concerning the pedagogical aspect, researchers, among others, have adapted special methods from pedagogy to reveal coaches' experience with game sense coaching (Pill 2015). They have made an attempt to analyze the learning process of coaches and their professional development. The particular nature of coaching children in sport has also been studied (Stattford 2011).

The coach-athlete relationship in connection with athletes' well-being has been explored as well (Davis $\&$ Jowett 2014). Likewise, athlete-coach relationships have been described from an athletic career perspective with the aim of exploring the athletes' subjective experiences of working with all of the coaches involved in their careers and to summarize their beliefs about the dynamics of athlete-coach relationships in the course of their careers (Sandström et al. 2016).

Football coaches have also frequently been at the center of scientific investigations. Some experts have studied professional English football coaches' behavior in their working environment (Potrac et al. 2007). Another research group examined the psychological preparation strategies often used by football coaches working with elite players and teams and the rationales for why these strategies were used (Freitas et al. 2013). Other researchers have examined the relationship between coaches' behavior and achievement motivations (Soyer et al. 2014), social networks in elite football coaching (Occhino 2013), coaches' philosophical profiles (Isidori et al. 2015), their professional development programs (Blair 2013), and their relationships with players (Vella et al. 2013). However, we could not find systematic research reports about their pedagogical beliefs.

\footnotetext{
${ }^{1}$ This paper is a modified version of the paper that was published under the same title in 2016 in A. Gál, J. Kosiewicz, \& T. Sterbenz (Eds.), Sport and Social Sciences with Reflection On Practice (pp. 77-92). Warsaw: AWF \& ISSSS.
} 


\section{Objectives}

This study is a report from a particular part of a comprehensive study aimed at revealing football coaches' pedagogical beliefs. From a rich storehouse of pedagogical beliefs based on a pilot study recently conducted by the author, this paper focuses on coaches' beliefs about education, their opinions about the most important tools of education, the content of human values transmitted during education, and their educational creeds.

Another major objective of this paper is to present some of the methodological problems of carrying out research in this field. Namely, the intention is to discern how the concept of a nationwide study on teachers' pedagogical views and the methods used in that examination can be adapted to coaches in the most proper and effective way. In critically examining coaches' educational beliefs, our initial hypothesis was that, as with other pedagogical beliefs, educational beliefs also differ according to the educational level of football coaches.

\section{Theoretical framework}

For the theoretical framework of our research, we chose conceptions of belief as well as academic concepts about how beliefs are shaped. In the literature we can find different approaches to beliefs. From those, we chose the one that played a basic role in the pedagogical research, which we considered as a pattern. According to Richardson,

"beliefs are thought of as psychologically held understandings, premises, or propositions about the world that are felt to be true," and "... are accepted as guides for assessing the future" (Richardson 1996, p. 103).

In addition, according to Richardson, the source of beliefs is personal or part of an educational experience. The author believes that beliefs and individual actions interact with each other:

"Beliefs are thought to drive actions; however, experiences and reflection on action may lead to changes in and/or additions to beliefs" (Richardson 1996, p. 104).

In analyzing a great quantity of literature, Pajares calls experts' attention to the fact that the characteristic of beliefs cannot be considered as "categorical truths but as fundamental assumptions that may reasonably be made when initiating a study of teachers' educational beliefs" (Pajares 1992, p. 324). He also emphasizes the significance of the following traits of beliefs:

a) "beliefs are formed early" and are difficult to change;

b) "the believing system has an adaptive function in helping the individual to define and understand the world and themselves...";

c) "knowledge and beliefs are intertwined" in a complex way-however, the assessment of beliefs inherently acts as a filter through which we can interpret new phenomena;

d) "the individual's beliefs greatly influence their behaviour"; and

e) teaching beliefs have already been developed and established by the time students are involved in higher education (Pajares 1992, pp. 324-325).

Falus (2002) also outlines that students entering teacher training have already gained a lot of experience in public education. He agrees with Richardson that these beliefs dominate in the subsequent acquisition of knowledge. Much like Pajares, Falus thinks that before choosing any occupation as a career, various effects are exerted on the students in and out of school that might even have an impact on the occupation they pursue. We think that this theorem can be valid for coaches as well. Thus, coaches' influence on their athletes not only depends on the beliefs they have formed through professional training, but also on their previous life experiences.

At the same time, we must not forget that Falus (2004) also highlighted the idea that some of the teachers' personality features, e.g., empathy and tolerance, do not evolve only in public and higher education, but also in other areas of life. In our opinion, this statement can hold for football coaches as well. These effects are not well known, and it is very difficult to examine them.

Changing one's beliefs is not an easy task. We are familiar with the phenomenon in which students participating in teacher training programs select the information, research results, and even the literature or 
experiences described by others based on their own preliminary beliefs and experiences (Zeichner \& Liston 2014).

According to Wubbels (1992), the main reason for the above-mentioned phenomenon is that the beliefs of a person are located in the right hemisphere of the brain, in contrast with theoretical knowledge, which is located in the left hemisphere; therefore, it is difficult to create a connection between the two. In other words, the fact that the students are provided with more and more knowledge does not ensure that their beliefs will change.

As Koerner (1963) expressed, many teachers are not able to convert their pedagogical principles into a special teaching strategy when they work. Moreover, the research of Combs et al. (1974) showed that both the "good" and the "bad" pedagogues are equally aware of what they should have done in a particular pedagogical situation. In spite of their knowledge, they often act differently based on their beliefs. Therefore, it is extremely important not only to influence teachers' beliefs but also to develop their awareness of them.

It is much more difficult to promote the above recommended process with students at the bachelor's level than at the master's level because a master's education is more personalized. For instance, teachers can find individual solutions for arising problems and can teach experimentally (Richardson 1996). Based on this, it can be rightly supposed that a higher level of education can contribute more to developing, reinforcing, or reshaping future coaches' beliefs than a lower level of education. It is necessary to learn more about coaches' pedagogical beliefs because the more familiar we are with them, the more we can understand their impact on the future generations of players.

\section{Methodological considerations}

In choosing a conceptual framework and methods for our research, we considered a comprehensive study conducted among teachers in public education at the turn of the century as the starting point. However, substantial changes had to be made due to differences in the characteristics of the two populations and in the available financial and human resources.

Taking into consideration the considerable differences in the main objectives of teachers' and coaches' activities and the dissimilarities between their occupational demands and circumstances as well as between their ways of life, the content of the questionnaire had to be modified. As a consequence of the limitation of human and material resources in our case, the data collection method had to be changed. In contrast to our research team of two, the investigation among the pedagogues was conducted by nine researchers.

For the above-mentioned reasons, we had to reduce the sub-topics and size of the questionnaire used with the pedagogues. Out of the 87 original interview questions (Golnhofer \& Nahalka 2001), we chose the 34 that were most relevant for the coaches. We were not able to collect the data with a semi-structural interview. Instead, based on the relevant parts of the interview scheme, we created a relatively independent questionnaire. We considered our study as preliminary research.

\section{Research methods}

In our research, we used the following methods. First, we conducted a pilot study. We gave the 34 open questions taken from the pedagogues' interview outlines to 25 football coaches who voluntarily participated in the research. Based on their responses and other theoretical considerations, we changed the relevant open questions to closed ones in such a way that we offered alternatives for answers and formulated multiple choice and Likert scale questions. Then we tested this questionnaire with a sample of 100 people.

\section{Research sample}

We intended to select a sample with a stratified, random sample of the same size, similar to the research with the pedagogues $(\mathrm{N}=100)$. However, right at the beginning we faced an obstacle that made this impossible: We could not find adequate statistical data concerning the total population. Thus we had to start collecting this data, and this process is still in progress. In the meantime, in the absence of this data, we selected the sample gradually at this stage. In the first stage, the sample was selected from different types of organizational units 
employing coaches, such as sport clubs, associations, independent professional football sections, and football academies. In the second stage, we invited all coaches working in the selected organizational unit to participate in the research.

The sample obtained in this way is representative only of coaches employed in the capital and countryside. As the total population's parameters were unknown, the findings must not be generalized; they are just moderate indicators of the total population's pedagogical beliefs. Notwithstanding, testing the questionnaire proved to be successful, and from this perspective our investigation reached its goal.

Our sample has the following characteristics:

- The coaches' age distribution in the sample is as follows: under 30 years, $26 \%$; $31-40$ years, 32\%; $50-60$ years, $12 \%$; above 60 years, $6 \%$.

- There was only one female in the sample; the gender distribution of the sample is irrelevant.

- The coaches' distribution according to professional qualifications is as follows: $55 \%$ have a higher qualification (UEFA PRO, UEFA A, UEFA B, MSc in coaching, BSc in coaching and in PE); 44\% have a basic or intermediate coaching qualification $\left(\mathrm{HFF}^{6} \mathrm{D}, \mathrm{HFF}\right.$ Grassroots $\left.\mathrm{C}\right)$. The level of one coaching professional qualification is unknown.

- The coaches' distribution according to the age group of the players they deal with is as follows: $74 \%$ work with junior players; $26 \%$ coach adults; and $10 \%$ work with both age groups. However, most coaches currently working with adult teams have previous experience with junior players.

\section{Data collection and data processing}

There are diverse methods for discovering individuals' beliefs-for instance, with the help of personal interviews, questionnaires, role repertory grids, supported evocation, concept maps, and metaphor analyses (Falus 2004). In our research, the data was collected with questionnaires that needed to be completed by the coaches in small groups. The author of this paper was present at this completion in order to give information to the respondents if they needed it and to prevent potential misunderstandings. The data were collected between September 12, 2012 and August 30, 2014.

Data processing was done using the SPSS 22 program. Besides the basic descriptive statistics, the Pearson's chi-square test was employed to learn more about the correlations.

\section{Results}

Of the coaches' pedagogical beliefs, their beliefs related to education were explored first. We developed a questionnaire from the interview outline of the research about the pedagogues' beliefs and we tested it from the responses given by the coaches participating in the pilot study. We collected information about the following sub-topics: interpretation of education, the most important influential tools of education, the content of human values transmitted during education, and educational creeds.

\section{Interpretation of education}

Understanding the interpretation of education was regarded as a priority during our research. First, similar to Lénárd and Szivák (2001), we presumed that, in principle, there is an unambiguous relationship between beliefs and activities. However, we changed our minds because even everyday observation suggests that it is not unfounded to assume the existence of pedagogical antinomy with coaches-namely, there is a contradiction between their practice and theory. At this stage of our research, our main aim was to describe the meaning of the term education for the coaches. At a later stage we tried to examine whether antinomy indeed exists between their interpretation of education and their coaching practice.

During the research, we divided the sample into two groups. The first group consisted of highly-qualified coaches with the following qualifications: UEFA PRO, UEFA A, UEFA B, MSc degree in coaching, and BSc

\footnotetext{
${ }^{2}$ HFF - Hungarian Football Federation (MLSZ)
} 
degree in coaching and in PE. The coaches with basic and intermediate coaching qualifications-that is, coaches with HFF D and HFF's Grassroots C qualifications-made up the second group. The first group consisted of 55 people; the second consisted of 44 people. Since one of the respondents did not specify his educational background, his answers were not taken into consideration.

Table 1. The coaches' interpretation of education according to professional qualification* $(\mathrm{N}=99)$

\begin{tabular}{|c|c|c|c|c|}
\hline \multirow[t]{2}{*}{ Response categories } & \multicolumn{2}{|c|}{$\begin{array}{l}\text { Coaches with higher education } \\
\qquad \mathrm{n}=55\end{array}$} & \multicolumn{2}{|c|}{$\begin{array}{l}\text { Coaches with lower education } \\
\qquad \mathrm{n}=44\end{array}$} \\
\hline & Rank & $\%$ & Rank & $\%$ \\
\hline $\begin{array}{l}\text { A coach should educate not just a football player } \\
\text { but also a human being. }\end{array}$ & 1. & 78.2 & 1. & 70.5 \\
\hline $\begin{array}{l}\text { A coach should recognize gifted athletes and } \\
\text { develop their abilities. }\end{array}$ & 4. & 38.2 & 3. & 38.6 \\
\hline A coach should lead by example. & 5. & 34.5 & 4. & 36.4 \\
\hline $\begin{array}{l}\text { A coach should educate athletes to respect the } \\
\text { game, their team, and their rivals, and to be a } \\
\text { good person in communities. }\end{array}$ & 2. & 45.5 & 2. & 52.3 \\
\hline $\begin{array}{l}\text { A coach should transfer their experiences to the } \\
\text { athletes. }\end{array}$ & 6. & 25.5 & 6. & 29.5 \\
\hline $\begin{array}{l}\text { A coach should develop their athletes' } \\
\text { individuality and personalities. }\end{array}$ & 3. & 41.8 & 5. & 31.8 \\
\hline
\end{tabular}

*The coaches had the chance to mark multiple answers from the alternatives.

Source: own study.

As Table 1 shows, nearly three-quarters of the coaches believe that education should not be restricted to the professional teaching of the athletes (in their case, the football players). Instead, it should incorporate the teaching of social norms and contribute to the socialization of the athletes. This is significant because according to Németh's model, which we also accept, socialization is a broader concept than education (Németh \& Boreczky 1997): socialization means becoming a social being, while education means making somebody a social being. The difference between these two approaches is that socialization is an indirect process, while education is a planned and deliberate action. This means that under ideal circumstances, football coaches can plan the educational process of their players. In the ranking, the transfer of general sporting values takes second place-around $50 \%$ of the coaches chose this response category. It is more than likely that a great number of coaches have normative conceptions about education. It seems that they have the intention to transfer basic human values to their players, and they strongly believe in the long-term impact of education.

The above-mentioned results reveal that there is a difference between the two sub-samples in the interpretation of education. The difference indicates that there are slightly more highly educated people who think that coaches should educate not only a good football player but also a good human being $(78.2 \%$ versus $70.5 \%)$. Moreover, a significant difference was registered in the two sub-samples between the coaches' opinions about the importance of transmitting general and specific values (chi-square value $6.54, \mathrm{p}<0.05$ ). More coaches with lower qualifications attributed importance to the transmission of general and sporting values. Third in the ranking was the promotion of the players' personalities and individuality. In this issue, a significant difference was also registered according to the coaches' professional qualifications (chi-square value 5.66, $\mathrm{p}<0.05$ ). More coaches who are more highly qualified interpret education as a tool for individual and personal development (41.8\% versus 31.8\%). Approximately one-third of the football coaches consider talent recognition, talent management, and leading by example as an integral part of their education. The transfer of experience finished in last place in the ranking with both sub-samples. This difference is not significant $(25.5 \%$ versus 29.5$)$. It seems that the coaches underestimate their personal example in their players' education. 


\section{Influential tools of education}

According to the football coaches in the sample, the highest educational impact can be achieved by consistency, professionalism, and setting a good example (Table 2).

Table 2. Football coaches' beliefs about the influential tools of education by professional qualification* $(\mathrm{N}=99)$

Coaches with higher education

$(\mathrm{n}=55)$

Rank

Response categories
Coaches with lower education

$(n=44)$

Rank \%

\begin{tabular}{lcccc}
\hline Patience & 6. & 29.1 & 5. & 27.3 \\
Setting an example & 2. & 54.5 & 3. & 40.9 \\
Consistency & 1. & 56.4 & 1. & 61.4 \\
Care & $4-5$. & 32.7 & 4. & 38.6 \\
Love & $4-5$. & 32.7 & 6. & 20.5 \\
Professional competence & 3. & 50.9 & 2. & 47.7 \\
Others & 7. & 20.0 & 7. & 2.3 \\
\hline
\end{tabular}

*The coaches had the chance to choose more than one answer from the alternatives.

Source: own study.

Data from Table 2 indicate that more than half of the coaches believe that the greatest educational impact can be induced by consistency. The beliefs of the coaches and the pedagogues as benchmarks differ from each other the most regarding this issue. More than half of the coaches think that consistency is highly important from the perspective of an educational effect, in contrast with pedagogues, where this ratio is one-fifth.

Professional competence and leading by example finished next in the ranking with $50 \%$. This result is not fully consistent with the findings concerning the interpretation of education. In that context, only approximately one-third of the coaches associated "leading by example" with education. Among the pedagogues, the response alternative for "leading by example" was considered to be the tool with the largest educational effect, and significantly more teachers chose this category: $67 \%$ of men, and $69.7 \%$ of women (Lénárd \& Szivák 2001, p. 46).

According to Bábosik (1999), personal example is effective only if the given teacher has high prestige. We can assume that the interviewed coaches believed that they had high authority among their players and set good examples for them to follow. The fact that the football coaches highlighted the importance of professional competence, consistency, and personal example indicates that they prefer direct methods in education and believe in traditional involvement, similar to the teachers.

On the other hand, considerable differences were recorded between the coaches' and pedagogues' beliefs regarding the possible educational impact of patience and love. Significantly more coaches emphasized the importance of patience and love in education than teachers. In addition, more than one-third of the coaches outlined that personal attention to athletes is a significant tool for influencing them.

\section{Educational values}

To explore the educational values of the coaches, we used the same closed questions that were used in the research with the pedagogues (Lénárd \& Szivák 2001). We listed several human values, the development of which can be the objective of education. The coaches scored these values according to their importance on a scale from 1 to 4 (Table 3).

Among the coaches with higher professional qualifications, the first three top-rated values were cooperation, sincerity, and effort. Coaches with lower qualifications also put effort and sincerity at the top. However, instead of cooperation, they put an intellectual value, creativity, third in the ranking.

Talent was consistently ranked lower, regardless of professional qualifications: eleventh place for coaches with higher qualifications, and tenth for coaches with lower qualifications. The value of the standard deviation is low in both groups. At first, this result seems to be surprising because talent has a special role in 
sport. Based on a deeper analysis, it can be supposed that with this value judgment, the coaches expressed their view according to which type of education cannot really develop talent.

Table 3. Coaches' opinions about the importance of educational values ( $\mathrm{N}=99)$

\begin{tabular}{lllllll}
\hline Educational values & \multicolumn{3}{l}{$\begin{array}{l}\text { Coaches with higher education } \\
(\mathrm{n}=55)\end{array}$} & \multicolumn{3}{l}{$\begin{array}{l}\text { Coaches with lower education } \\
(\mathrm{n}=44)\end{array}$} \\
& Rank & Average & Distribution & Rank & Average & Distribution \\
\hline Intelligence & $7-8$. & 3.22 & 0.81 & 8. & 3.25 & 0.84 \\
Self-realization & 10. & 3.02 & 1.34 & 12. & 2.98 & 0.80 \\
Cooperation & 1. & 3.56 & 0.96 & $6-7$. & 3.36 & 0.69 \\
Ability to adapt & $7-8$. & 3.22 & 1.10 & 4. & 3.41 & 1.31 \\
Creativity & 5. & 3.27 & 1.10 & 3. & 3.43 & 0.82 \\
Talent & 11. & 3 & 0.88 & 10. & 3.11 & 0.99 \\
Autonomy & 12. & 2.95 & 1.11 & 5. & 3.26 & 1.07 \\
Self-knowledge & 6. & 3.25 & 1.08 & 9. & 3.18 & 0.87 \\
Venturesomeness & 9. & 3.07 & 1.01 & 11. & 3.05 & 0.94 \\
Discipline & 4. & 3.45 & 1.23 & $6-7$. & 3.36 & 0.94 \\
Sincerity & 2. & 3.55 & 1.01 & 2. & 3.52 & 1 \\
Effort & 3. & 3.51 & 0.98 & 1. & 3.66 & 1.12 \\
\hline
\end{tabular}

Source: own study.

Like the teachers, the coaches also evaluated venturesomeness poorly as a human value. Autonomy was even less appreciated, particularly among the coaches with a higher professional qualification, which suggests an authoritarian way of thinking. It has to be noted that this mentality is not too different from the teachers' attitudes; in their ranking of human values, autonomy is situated in the middle.

On the whole, both the teachers and coaches preferred more collective and moral values than individualistic ones; the latter were ranked much lower.

These results also confirm the assumption that, as football is a team sport, football coaches mainly determine the direction of education along collective values. Their conception about educational values is consistent with their interpretation of the term "education." Based on this, coaches should teach players to respect the game, their team, and their rivals, and to be a good person in communities (see Table 1). It seems that the majority of football coaches subordinate the educational process to collective values.

In view of the means, there are no radical differences between the teachers' and coaches' evaluation of the examined educational values. The two extreme values of the means with the more highly qualified coaches are 2.95 and 3.56; with the less qualified coaches, these values are 2.98 and 3.66. In the case of the teachers, the values of the two extreme means were 2.90 and 3.92. The coaches regarded the examined human values as being closer to each other than the teachers did.

\section{Educational creeds}

The coaches had to evaluate 17 education-related statements on a Likert scale of 1 to 4 in order to determine their educational creeds. Depending on how much they agreed with the statements, they scored them along the scale. The lowest degree of agreement with a statement was indicated with a 1 ; the highest was indicated with a 4 (Table 4). 
Table 4. The coaches' educational creeds $(\mathrm{N}=99)$

\begin{tabular}{|c|c|c|c|c|c|c|c|}
\hline \multirow[t]{2}{*}{ Statements } & \multirow{2}{*}{$\begin{array}{l}\text { Total } \\
\text { Rank }\end{array}$} & \multicolumn{3}{|c|}{$\begin{array}{l}\text { Coaches with higher } \\
\text { education } \\
(\mathrm{n}=55)\end{array}$} & \multicolumn{3}{|c|}{$\begin{array}{l}\text { Coaches with lower } \\
\text { education } \\
(\mathrm{n}=44)\end{array}$} \\
\hline & & Rank & Mean & St dev & Rank & Mean & $\begin{array}{c}\text { St } \\
\text { dev }\end{array}$ \\
\hline $\begin{array}{l}\text { The personality of young players is formed mainly in } \\
\text { the family; coaches have little impact on it. }\end{array}$ & 11. & 11. & 2.38 & 1.01 & 11. & 2.52 & 0.98 \\
\hline $\begin{array}{l}\text { The coach's personality is more decisive than their } \\
\text { professional qualifications. }\end{array}$ & 5. & 8. & 2.91 & 0.95 & 3. & 3.27 & 1.15 \\
\hline $\begin{array}{l}\text { The freedom granted to the athletes may later have an } \\
\text { adverse effect. }\end{array}$ & 10. & 10. & 2.71 & 0.88 & 12. & 2.25 & 0.97 \\
\hline $\begin{array}{l}\text { In an age group, each team should consist of athletes of } \\
\text { similar ability. }\end{array}$ & $14-15$. & 16. & 1.89 & 1.06 & 14. & 2.07 & 1.10 \\
\hline $\begin{array}{l}\text { Coaches should educate athletes about the rules of } \\
\text { coexistence. }\end{array}$ & 9. & 9. & 2.73 & 0.80 & 8. & 2.84 & 1.03 \\
\hline $\begin{array}{l}\text { Basically, all athletes are similar; the differences } \\
\text { between them are just superficial. }\end{array}$ & 17. & 17. & 1.44 & 0.76 & 17. & 1.68 & 0.88 \\
\hline $\begin{array}{l}\text { A coach who does not create a competitive situation for } \\
\text { his athletes does not motivate them adequately. }\end{array}$ & 3. & 3. & 3.16 & 1.17 & 5. & 3.13 & 1.32 \\
\hline $\begin{array}{l}\text { Children coming from a disadvantaged social } \\
\text { environment usually react indifferently to coaches' } \\
\text { evaluations. }\end{array}$ & $14-15$ & 14. & 1.98 & 1.39 & 15. & 1.96 & 0.89 \\
\hline $\begin{array}{l}\text { The sport culture of a child's family has a stronger } \\
\text { impact on their development than their application and } \\
\text { efforts in workouts. }\end{array}$ & 12. & 13. & 2.27 & 1.28 & 10. & 2.57 & 0.93 \\
\hline $\begin{array}{l}\text { Being a coach is a profession; not just anyone can be a } \\
\text { good coach. }\end{array}$ & 1. & 1. & 3.86 & 0.52 & 1. & 3.77 & 0.60 \\
\hline $\begin{array}{l}\text { Children must first be taught to distinguish between } \\
\text { good and bad, and only then should they be encouraged } \\
\text { to be independent and critical. }\end{array}$ & 6. & 7. & 2.94 & 1.03 & 6. & 3.07 & 1.32 \\
\hline $\begin{array}{l}\text { There is no "better" or "worse" team, only a better or } \\
\text { worse coach. }\end{array}$ & 16. & 15. & 1.95 & 0.99 & 16. & 1.77 & 0.83 \\
\hline $\begin{array}{l}\text { All athletes are good at first; any bad features that arise } \\
\text { later are rooted in the mistakes of their education. }\end{array}$ & 8. & 6. & 2.96 & 0.94 & 9. & 2.79 & 0.95 \\
\hline $\begin{array}{l}\text { Innate capabilities play a fundamental role in achieving } \\
\text { success in sport. }\end{array}$ & 2. & 2. & 3.40 & 0.68 & 2. & 3.47 & 0.66 \\
\hline $\begin{array}{l}\text { Punishment in sport and in education is as necessary as } \\
\text { rewards. }\end{array}$ & 7. & 5. & 3.04 & 0.99 & 7. & 2.93 & 1.10 \\
\hline $\begin{array}{l}\text { One of the important tasks for a coach is to support } \\
\text { their athletes' self-realization. }\end{array}$ & 4. & 4. & 3.07 & 0.89 & 4. & 3.20 & 0.67 \\
\hline $\begin{array}{l}\text { Liberal pedagogy mostly fails in sport because, } \\
\text { generally, it falls into indiscipline. }\end{array}$ & 13. & 12. & 2.29 & 1.01 & 13. & 2.09 & 0.88 \\
\hline
\end{tabular}

Source: own study.

The ranking of the statements shows a heterogeneous picture of the coaches' educational creeds. Regardless of professional qualifications, the following statement can be found at the top of the ranking: "Being a coach is a profession; not just anyone can be a good coach." The mean of the evaluation of this statement for the coaches with higher professional qualifications is 3.86; for the coaches with lower qualifications, it is 3.77. The coaches involved in our research consider their job as a labor of love and not just as a task to be carried out, and they highly appreciate their own role. Many of them believe that their personality is more important than their professional qualifications. In this question, there is a significant difference between the opinions of the two sub-samples. The coaches with a higher education appreciate higher 
professional qualifications ( $3^{\text {rd }}$ place in the ranking; mean, 3.27) than the coaches with lower ones $\left(8^{\text {th }}\right.$ place in the ranking; mean, 2.91), with the latter providing a better ranking for the importance of the coach's personality. Generally speaking, the coaches truly believe that their committed personality really affects their activities. This view is also reflected by the large rejection of the statement that the personality of young players develops mainly in the family and the coach has little impact on it $\left(11^{\text {th }}\right.$ place in the ranking; low standard deviation). On the other hand, they agree with the position that innate capabilities play a decisive role in achieving success in sport. Almost all coaches, regardless of their professional qualifications, believe that a player cannot be successful without innate talent ( $2^{\text {nd }}$ place in the ranking; very low standard deviation). At the same time, a great number of them are of the opinion that one of the most important roles of coaches is to support the self-realization of their players ( $4^{\text {th }}$ place in the ranking; mean over 3; low standard deviation). In addition, they have to teach their players the rules of coexistence ( $9^{\text {th }}$ place in the ranking; mean close to 3$)$, and especially the ability to distinguish between good and bad ( $6^{\text {th }}$ place in the ranking; mean close to 3$)$.

Regardless of their professional qualifications, the majority of the coaches agree with the statement that creating a competitive situation for their athletes is one of their duties (mean is 3.16, 3.13). Understandably, unlike the teachers, the coaches are convinced that a very important element of their activities is to support their athletes' participation in competition. Only half of them expect education to cover respect for the opponent (Table 1).

The coaches and the teachers rejected the same statements in the highest degree (see the last places: 14$15^{\text {th }}, 16^{\text {th }}$, and $17^{\text {th }}$ in the ranking), but their argumentation is partly different. For many young athletes coming from disadvantaged social backgrounds, their sporting activity and their coach might be extremely important to them. Therefore, they are not indifferent to their coach's remarks, which might play an accentuated role in their lives.

\section{Discussion and conclusions}

Contrary to common belief and their observable performance-oriented behavior at times, coaches can be considered as pedagogues both professionally and scientifically. Presumably less consciously and systematically than teachers, coaches, and implicitly also football coaches, regularly mobilize their pedagogical beliefs in their work. Although these pedagogical beliefs may influence their decisions and opinions about their players and about other actors in sport, so far they have rarely been the subject of extensive research. We have recently tried to bridge this gap by conducting a comprehensive study about football coaches' pedagogical beliefs on an experimental basis. Based on this research, we presented some results from their pedagogical beliefs related to their educational beliefs, and we discussed some relevant methodological problems.

The results obtained in the study revealed that although the football coaches had a partly positive approach to pedagogical beliefs, preconceptions about their one-sidedness are not unfounded.

A favorable phenomenon is that, though this was not true for all of them, many football coaches declared that their intention was not only to educate football players, but human beings in general. In turn, it is an unfavorable fact that more than half of the interviewed football coaches interpret the concept of education imperfectly; they do not include in this concept the necessity for the development of players' personalities and for contributing to community building. Even more football coaches underestimate the importance of transmitting experiences and leading by example when interpreting the term "education." At the same time, when listing the most important effects of education, the coaches with higher professional qualifications highlight the significance of providing a good personal example to the players. The educational effects are ranked differently by the football coaches and the teachers. The main reasons for this difference in opinion are twofold: they may partially originate from many teachers' apathy and exhaustion, and partially from the coaches' recognition that, in contrast to compulsory public education, young people would choose regular sporting activity only as long as they feel care and goodwill from their coaches.

The findings also referred to many similarities between the coaches and teachers concerning their assessment of human values, both in positive and negative directions. Negative trends are mainly indicated by 
their collective rejection of promoting young people's independence and venturesomeness. This way of thinking shows that the concept of traditional authoritarian education survives in both teachers and coaches and suggests that there might be many authoritarian personalities within both groups.

On the whole, we can conclude that the assumptions, according to which the coaches' educational beliefs depend, to a great extent, on the level of their professional qualification, were only partly confirmed. It proved to be true that coaches with different levels of professional qualifications assessed the importance of their own professional qualifications differently; not accidentally, the higher the level of the qualification, the more appreciation the coach had for it. Unambiguous differences were also found between the two groups in the judgment of the significance of transmitting human values and of developing the personalities of the players.

However, besides considerable differences, there are also fundamental similarities in educational beliefs between coaches with higher and lower professional qualifications, especially in their job-related educational beliefs. For instance, most members in both groups are of the opinion that to be a coach is not just a job, but a profession. Moreover, they admit the importance of innate talent, highly appreciate the role of consistency in education, and place great value on the players' participation in competition. They also consider the competitive environment as an important educational tool.

In analyzing the explanation and interpretation of the results, we cannot ignore the fact that the data cannot be generalized because the sample is not representative. On the other hand, we can state that the adaptation of the theoretical concept and the methods of the nationwide research for studying teachers' pedagogical values proved to be suitable for an examination of coaches' pedagogical beliefs. The practical modification of the methods for data collection we carried out proved to be a success. With the help of the answers received in the course of the pilot study carried out among football coaches, we were able to create adequate answer alternatives for responses, which only needed minor amendments. The changes we made in the series of statements used for discovering the educational beliefs of teachers also seem to be effective. Only a few statements had to be converted into more sport-specific ones, which will certainly be implemented in the next phase of our research.

An indirect objective of this research was to contribute to an increase in the level of training for coaches and to help them become good pedagogues. Football coaches should be taught to use teaching "tricks" correctly and adequately in their daily work and, by this, to promote a good coach-athlete relationship. There is no doubt that a scientifically founded knowledge about the educational beliefs of football coaches can support the effectiveness of this process. The content of coaches' pedagogical beliefs is of particular importance in their training since it can strengthen and transform their original beliefs and help them become successful pedagogues of sport, both morally and intellectually.

\section{REFERENCES}

Bábosik, I. (1999). A nevelés elmélete és gyakorlata [The theory of education and practice]. Budapest: Nemzeti Tankönyvkiadó.

Blair, R. (2013). An evaluation of a continuing professional development programme for community football coaches delivering Physical Education lessons in primary schools. PhD Thesis, Brunel University. Retrieved June 13, 2016, from http://bura.brunel.ac.uk/bitstream/2438/7588/3/FulltextThesis.pdf

Combs, A.W., Blume, R.A., Newman, A.J., \& Wass, H.L. (1974). The Professional Education of Teachers: A

Humanistic Approach to Teacher Education. Boston: Allyn and Bacon Inc.

Davis, L. \& Jowett, S. (2014). Coach-athlete attachment and the quality of the coach-athlete relationship: Implications for athlete's well-being. Journal of Sports Sciences, 32(15), 1454-1464.

Falus, I. (2002). A pedagógusképzés modelljei az Európai Közösség országaiban [Models of the pedagogue's training in the countries of the European Community]. In I. Bábosik \& A. Kárpáti (Eds.), Összehasonlitó pedagógia

[Comparative pedagogy] (pp. 87-106). Budapest: Nemzeti Tankönyvkiadó.

Falus, I. (2004). A pedagógussá válás folyamata [The process of becoming a pedagogue]. Educatio, 13(3), 359-374.

Freitas, S., Dias, C., \& Fonseca, A. (2013). How do elite soccer coaches prepare their players and teams psychologically? Journal of Physical Education and Sport, 53, 321-329.

Golnhofer, E. \& Nahalka, I. (Eds.). (2001). Pedagógusok pedagógiája [Pedagogues' pedagogy]. Budapest: Nemzeti Tankönyvkiadó. 
International Council for Coaching Excellence \& Association of Summer Olympic International Federations. (2012). International Sport Coaching Framework. Illinois: Human Kinetics.

Isidori, E., Migliorati, M., Maulini, C., \& Echazarreta, R.R. (2015). Educational paradigms and philosophy of football coaching: A theoretical and practical perspective. Procedia-Social and Behavioral Sciences, 197, 614-621.

Koerner, J.D. (1963). The Miseducation of American Teachers. Baltimore: Penguin Books.

Lénárd, S. \& Szivák, J. (2001). Neveléssel kapcsolatos nézetek [Education-related views]. In E. Golnhofer \& I. Nahalka (Eds.), Pedagógusok pedagógiája [Pedagogues’ pedagogy] (pp. 36-64). Budapest: Nemzeti Tankönyvkiadó.

Németh, A. \& Boreczky, Á. (Eds.). (1997). Nevelés, gyermek, iskola [Education, children, school]. Budapest: Eötvös József Könyvkiadó.

Occhino, J. (2013). Dynamic Social Networks in High Performance Football Coaching. Retrieved August 12, 2016, from https://eric.ed.gov/?id=EJ1005060

Pajares, M.F. (1992). Teachers' beliefs and educational research: Cleaning up a messy construct. Review of Educational Research, 62(3), 307-332.

Pill, S. (2015). Using Appreciative Inquiry to explore Australian football coaches' experience with game sense coaching. Sport, Education and Society, 20(6), 799-818.

Potrac, P., Jones, R., \& Cushion, C. (2007). Understanding power and the coach's role in professional English soccer: A Preliminary investigation of coach behaviour. Soccer \& Society, 8(1), 33-49.

Richardson, V. (1996). The role of attitudes and beliefs in learning to teach. In J. Sikula (Ed.), Handbook of Research on Teacher Education (pp. 102-119). New York, NY: Macmillan.

Sandström, E., Linne'r, L., \& Stambulova, N. (2016). Career profiles of athlete-coach relationships: Descriptions and interpretations. International Journal of Sports Science \& Coaching, 11(3), 395-409.

Soyer, F., Sarı, I., \& Talaghir, L.G. (2014). The relationship between perceived coaching behaviour and achievement motivation. A research in football players. Procedia-Social and Behavioral Sciences, 152, 421-425.

Stattford, I. (2011). Coaching Children in Sport. New York, NY: Routledge. Retrieved August 11, 2016, from https://books.google.hu/books?isbn=1136964088

Szabó, S.A. (2012). What is the meaning of sport coaching? (Expectations, possibilities, realities). Sport SPA, 9(2), 3944.

Vella, S., Oades, L.G., \& Crowe, T.P. (2013). The relationship between coach leadership, the coach-athlete relationship, team success, and the positive developmental experiences of adolescent soccer players. Physical Education and Sport Pedagogy, 18(5), 549-561.

Wubbels, T. (1992). Taking account of student teachers' preconceptions. Teaching and Teacher Education, 2, 137-149.

Zeichner, K.M. \& Liston, D.P. (2014). Reflective Teaching: An Introduction (2 ${ }^{\text {nd }}$ ed.). New York, NY: Routledge. Retrieved July 24, 2016, from https://books.google.hu/books?isbn=1135037841

\section{AUTHOR'S ADDRESS: $\quad$ Daniel Varga}

University of Physical Education in Budapest

Alkotás u. 44, Budapest

1123 Hungary

E-mail: varga.daniel@tf.hu

Received: 24 October 2017; Accepted: 15 November 2017 